QK110

. 12317

B3

Barnhart, John Hendley

The dates of Rafinesque's

new flora and flora telluriana 


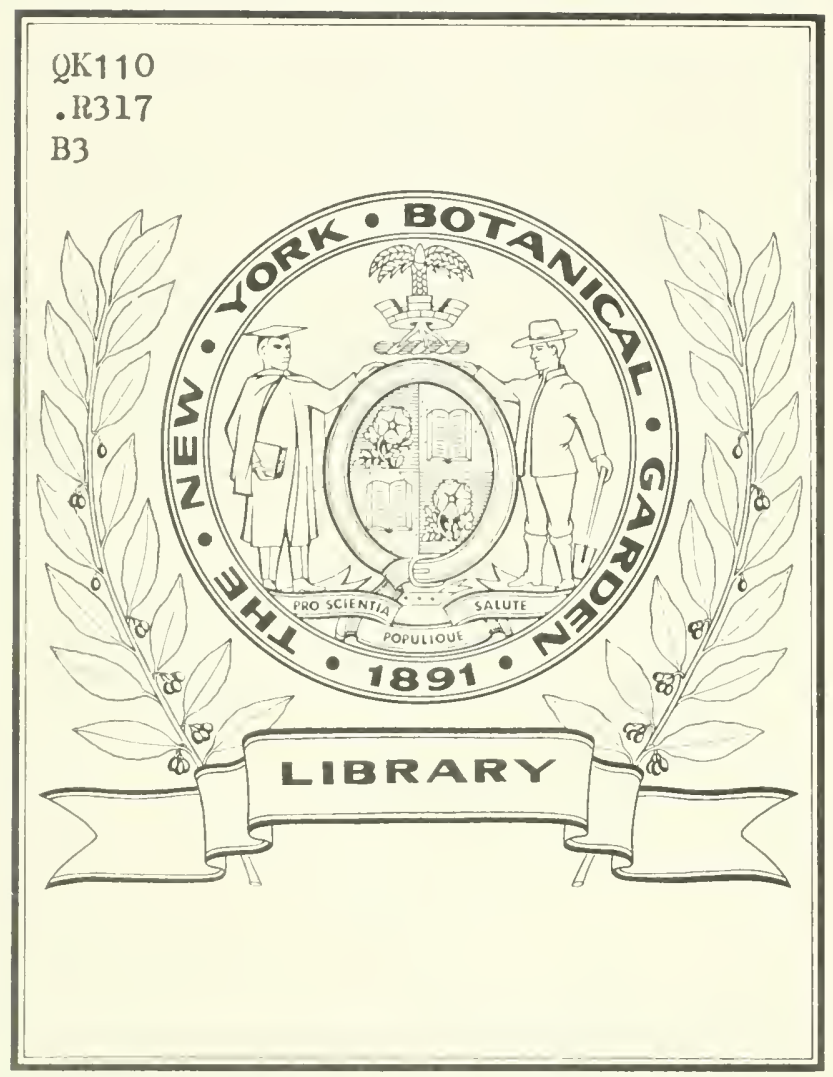






\section{THE DATES OF RAFINESQUE'S NEW FLORA AND FLORA TELLURIANA}

BY JOHN HENDLEY BARNHART

As far as I am aware, no question has ever been raised concerning the reliability of the dates given on the title-pages of any of the works of Rafinesque. His Autikon Botanikon, to be sure, is dated I 8 I5-I 840 , while no portion of the text was published until I 840 ; but this text was intended to illustrate an herbarium which the author had accumulated during the years i 8 I $5-1840$, so that the meaning of the date he gives is manifest.

About a year ago I noticed in the Flora Telluriana $(4: 27)$ a brief criticism of Gray's monograph of the Melanthaceae of North America, which was not published until November, I 837 ; $*$ and this, of course, showed that Rafinesque's criticism could not have been published earlier than that date. A hurried examination revealed further internal evidence of the erroneous dating of the Flora Telluriana and its companion-work, the New Flora of North America, but the investigation of the subject was not carried very far at that time.

When the last number of the North American Flora was in press, it became necessary for Dr. Small to decide upon the relative priority of Mesymizm Raf. (" 1836 ") and Cathartolinum Reichenb. ( 1837 ), and this led to the study of which the results are here reported.

The New Flora of North America was undertaken by Rafinesque as a supplement to the works previously published by others upon the same topic; and as a result of his labors upon

* Gray, A. Melanthacearum Americae Septentrionalis Revisio. Ann. Lyc. Nat. Hist. N. Y. 4 : 105-140. N 1837 . 
it, he was led to undertake the preparation of its "sequel," the Flora Telluriana, dealing with the plants of the rest of the world. The pages of these two works contain many descriptions of "new genera" of plants, so that the dates of their appearance are of considerable importance. As the books themselves are quite scarce, a brief preliminary account of them may not be out of place.

Each was planned to consist of six "parts" or volumes, but was completed in four. Each of the eight parts is separately paged, and has a separate title-page and subtitle of its own; and each is dated " I $8_{3} 6 . "$

\section{New Flora and Botany of North America}

First part. Introduction, Lexicon, Monographs. Ioo pages. I 836 .

Second part. Neophyton. 96 pages. 1836 .

Third part. New Sylva. 96 pages. I 836 .

Fourth part. Neobotanon. I I 2 pages. I 836 . (This contained also a general title-page for the entire work, dated i 836 .)

\section{Flora Telluriana}

First part. Introduction and Classification. I 03 pages. I 836 . Second part. Centuria I, II, III, IV. I I 2 pages. I 836 . Third part. Centuries V, VI, VII, VIII. Ioo pages. I $8_{3} 6$. Fourth part. Centuries IX, X, XI, XII. I 35 pages. I 836 .

(This contained also a general title-page for the entire work dated I $_{3} 6$.)

Of these eight parts, the first part of the New Flora was the first to appear. It contained a dedication dated at Philadelphia, September, 1836 ; and pages $73-80$ are occupied by a monograph of the genus Kuhnia, dated October, ${ }_{3} 8_{3} 6$. These facts alone are sufficient to make one suspect that perhaps the eight parts were not all issued before the end of that year! There is not lacking other internal evidence on this subject, in addition to the citation of Gray's monograph (Fl. Tell. 4:27; also New Fl. 4: IO3, where the date of "Grey's" paper is distinctly stated as " 1837 "). Flora Telluriana, part 3 (which in turn is cited by 
New Fl. $3: 4$ I, 5I), on page 57 refers to Bot. Reg. pl. 1906 (I $\mathrm{N}$ I 836 !); and on page 37 to Bot. Mag. pl. 35 fo (i D 1836 !), which could not well have reached Philadelphia before the end of the year $8_{3} 6$. Flora Telluriana, part 4 (which in turn is cited by New F1. $4: 56,57,63,98$ ), on page I 24 cites Bot. Reg. pl. $195 \mathrm{~S}$ ( I $\mathrm{My} \mathrm{I}_{\mathrm{I}} \mathrm{S}_{37}$ ). But, in spite of these references, I know of no internal evidence that the two works were not completed before the end of the year $1 \$ 37$.

From internal evidence, too, it is possible to arrange the parts serially, in the order in which they were printed. This may be done by means of the exact citations, by page, of one work by the other; chiefly of the Flora Telluriana by the New Flora. The result is as follows: New Fl. I; Fl. Tell. I; Fl. Tell. II ; New Fl. II ; Fl. Tell. III ; New Fl. III ; Fl. Tell. IV; New Fl. IV.

In order to approximate more closely than might otherwise be possible the exact dates of issue of each of these parts, the series of letters written to Torrey by Rafinesque during the years I $8_{3} 6$ to 1839 , and preserved in the Torrey correspondence at the New York Botanical Garden, was searched, and the search was well rewarded, as is shown by the following quotations:

September 5, I 836.- "I having leisure have resolved to begin to print my New flora of North Amer. by alphabetical order... When this Work is printed, my botanical labors from 1802 to 1836 , in America, will be better known."

December 21, I 836 . - " My flora proceeds very slowly \& was even suspended awhile for lack of a compositor that could print Botanical terms! . . . I have concluded to close the Lexicon of monographs very abruptly, and give instead selected monographs \& my N. Genera \& species."

This shows that only ten days before the close of the year I $8_{3} 6$ even the printing of the first part of the New Flora was not completed.

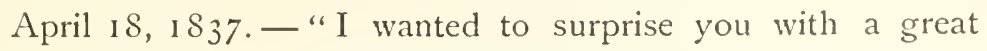
Botanical Work - my Flora telluriana . . . to which I was led by my New flora of $\mathrm{N}$. Amer., but I could only print 2 parts or volumes. I. Classes \& Orders. 2d. 400 N. Gen. my other engagts have compelled me to suspend for a while." 
By the middle of April, I837, then, had been printed one pa of the New Flora and two of the Flora Telluriana.

October 24, I837. - "I am still going on slowly with $\mathrm{m}$ New flora of N. America and Flora telluriana at once. have circulated but few copies of the numbers published, wishin to surprise you and all Botanists when the whole shall be ou but if you wish to see them earlier I may send you 5 numbe of 100 pages 8 vo each very soon, and more next March."

From this it appears likely that a second number of the Ne Flora had appeared when this letter was written, and that a thin number of the Flora Telluriana was nearly ready; or else th. the two parts were nearly ready to be issued together.

January Io, I $\&_{3} 8$. - " My New flora or Mantissa begun print in 1836 is still going on \& altho' interrupted by my flo Telluriana \& 2 works published this Spring ( 2. Safe Banking) is proceeding as fast as correct exam. can allor I wished to issue the whole work together; but I shall be con pelled to issue when half is ready 3 numbers of 100 pages as Flora tellur. My $3 \mathrm{~d}$ N. on the Trees and Shrubs or a Ne sylva is not quite ready."

At the end of $1 S_{37}$, then, three numbers of the Flora Tellur ana had been issued, and two of the New Flora, but on Januan ro, I $8_{3} 8$, the third part of the New Flora was " not quite ready

March 20, I 838 . - "I have long ago concluded 600 pages my Supplemental Flora \& Flora Telluriana or 6 parts. If I ha not undertaken these 2 works together, the first would have bec completed ere now, but will be ere i $\$ 40$."

The third part of the New Flora had evidently been publishe since the date of the January letter. It appears that Rafinesqu still intended each work to consist of six parts, and for this reasc allowed himself until i 840 to complete them.

February r, r839. - "My $4^{\text {th }}$ part or Volume of New flor was completed so as to give you time to go on with your flor I also completed my Flora telluriana in 4 Vol. or 1225 article But immed ${ }^{y}$ after begum \& have concluded last $\operatorname{Dec}^{r} \mathrm{~m}$ Synopsis of N. G. \& Sp. of Trees \& Shrubs of N. Amer."

From this it appears that prior to December, $1 \delta_{3} 8$, both th 
Flora Telluriana and the Ncw Flora had been completed. The last sentence refers to Rafinesque's Alsographia Americana, which was dated ${ }_{1} S_{3} S$, and from his own statement above was probably issued in December of that year.

The extracts from Rafinesque's letters show that few, if indeed any, copics of either the Flora Telluriana or the New Flora had been actually distributed until three parts of each had been printed (in the spring of $I_{3} S$ ); but, as he says in the letter of October 24,1837 , "I have circulated but few copies of the numbers published," we must give him the benefit of the doubt, and assume that he had distributed a few copies.

Rafinesque's Bulletin of the Historical and Natural Sciences was an advertising sheet issued by him at irregular intervals from

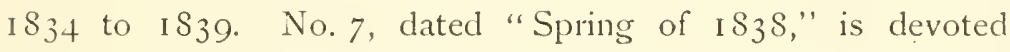
chiefly to the two works here under discussion. He says in part : "I had long contemplated to give a New Flora of North America. ... I resolved . . . to add the improvements on Natural classification. These last, however, increased so much under my revision, as to become a work by itself, and a companion rather than addition to our Flora. Both works were begun in $\delta_{3} 6$, and our plants would all have been published by this time, if I had not thus been compelled to double these botanical labors. I once proposed to issue the whole at once when completed, but this delay and others arising from different pursuits and labors, have induced me to publish the parts as soon as printed, and now that 3 parts of each (being half a volume, are published, I issue this Bulletin to acquaint the Botanists of Europe and America with" them. "Each work is to consist of 6 parts of IOO to I 20 pages, thus forming a volume large octavo of 600 to 700 pages, which shall be completed in 1840 or sooner. . . The 6 parts now printed, 3 of each work, will be sold together for \$5."

The dates of the two works under discussion, as nearly as they can be determined from the evidence here submitted, may be summarized as follows :

New Flora

Part

I. ${ }_{3} 6$ (December).

II. 1337 (second half).

III. $I_{3} 8$ (first quarter).

IV. I ${ }_{3} S$ (late in year). 
Flora Telluriana. Part I. I 837 (first quarter).

II. 1837 (first quarter).

III. I 837 (November or December).

IV. I 838 (near middle of year).

New York Botanical Garden. 




